\title{
HUBUNGAN KEPEMIMPINAN PELAYAN, KOMPETENSI MANAJERIAL KEPALA SEKOLAH, BUDAYA ORGANISASI, DAN MOTIVASI KERJA DENGAN KINERJA GURU DI GUGUS PAUD TUNJUNG KECAMATAN DENPASAR UTARA
}

\author{
Ni Luh Putu Sri Laksmi, A.A. Gede Agung, Sudirman \\ Jurusan Administrasi Pendidikan \\ Universitas Pendidikan Ganesha \\ Singaraja, Indonesia \\ e-mail: srilaksmibali@gmail.com, agungtps2056@gmail.com,
dirman_p@yahoo.co.id
}

\begin{abstract}
Abstrak
Kinerja guru di gugus PAUD Tunjung Kecamatan Denpasar Utara menunjukkan kecenderungan rendah, yang menyebabkan rendahnya mutu pendidikan. Rendahnya kinerja guru tersebut, diduga dipengaruhi oleh beberapa faktor. Faktor internal seperti: motivasi kerja, etos kerja, dan lain-lain. Sedangkan faktor eksternal seperti: kepemimpinan kepala sekolah, kompetensi manajerial kepala sekolah, budaya organisasi, dan lain-lain. Oleh karena itu, penelitian ini bertujuan untuk mengetahui hubungan kepemimpinan pelayan, kompetensi manajerial kepala sekolah, budaya organisasi, dan motivasi kerja dengan kinerja guru. Penelitian ini diadakan di gugus PAUD Tunjung Kecamatan Denpasar Utara menggunakan pendekatan ex-post facto dengan populasi subyek yaitu guru PAUD sejumlah 50 orang. Teknik pengambilan sampel menggunakan studi populasi. Data dianalisis dengan menggunakan analisis jalur (path analysis). Hasil penelitian menunjukkan bahwa (1) Ada hubungan yang signifikan antara kepemimpinan pelayan dengan motivasi kerja dengan koefisien jalur sebesar 0,433 (2) Ada hubungan yang signifikan antara kompetensi manajerial kepala sekolah dengan motivasi kerja dengan koefisien jalur sebesar 0,209 (3) Ada hubungan yang signifikan antara budaya organisasi dengan motivasi kerja dengan koefisien jalur sebesar 0,297 (4) Ada hubungan yang signifikan antara kepemimpinan pelayan dengan kinerja guru dengan koefisien jalur sebesar 0,132 (5) Ada hubungan yang signifikan antara kompetensi manajerial kepala sekolah dengan kinerja guru dengan koefisien jalur sebesar 0,398 (6) Ada hubungan yang signifikan antara budaya organisasi dengan kinerja guru dengan koefisien jalur sebesar 0,056 (7) Ada hubungan yang signifikan antara motivasi kerja dengan kinerja guru dengan koefisien jalur sebesar 0,320 (8) Ada hubungan secara tidak langsung antara kepemimpinan pelayan dengan kinerja guru melalui motivasi kerja (9) Ada hubungan secara tidak langsung antara kompetensi manajerial kepala sekolah dengan kinerja guru melalui motivasi kerja (10) Ada hubungan secara tidak langsung antara budaya organisasi dengan kinerja guru melalui motivasi kerja (11) Ada hubungan secara simultan yang signifikan antara kepemimpinan pelayan, kompetensi manajerial kepala sekolah, budaya organisasi dengan kinerja guru melalui motivasi kerja (12) Ada hubungan secara simultan yang signifikan antara kepemimpinan pelayan, kompetensi manajerial kepala sekolah, budaya organisasi, dan motivasi kerja dengan kinerja guru. Kesimpulan dari penelitian ini adalah ada Hubungan kepemimpinan pelayan, kompetensi manajerial kepala sekolah, budaya organisasi, dan motivasi kerja dengan kinerja guru di gugus PAUD Tunjung Kecamatan Denpasar Utara.
\end{abstract}

Kata kunci: kepemimpinan pelayan, kompetensi manajerial, budaya organisasi, motivasi kerja, kinerja guru

\section{Abstract}

The teacher's performance in the PAUD Tunjung in North Denpasar District showed a low tendency, which caused low quality of education. The low performance of these teachers is thought to be influenced by several factors. Internal factors such as: work motivation, work ethic, and others. While external factors such as: leadership of the principal, managerial competence of the principal, 
organizational culture, and others. Therefore, this study aims to determine the relationship of servant leadership, principal managerial competence, organizational culture, and work motivation with teacher performance. This research was conducted in the PAUD Tunjung in North Denpasar District using an ex-post facto approach with a population of 50 PAUD teachers. The sampling technique uses population studies. Data were analyzed using path analysis. The results showed that (1) There was a significant relationship between servant leadership and work motivation with a path coefficient of 0.433 (2) There was a significant relationship between principals' managerial competencies and work motivation with a path coefficient of 0.209 (3) There was a significant relationship between organizational culture with work motivation with a path coefficient of 0.297 (4) There is a significant relationship between servant leadership and teacher performance with a path coefficient of 0.132 (5) There is a significant relationship between principal managerial competencies and teacher performance with a path coefficient of 0.398 (6) There is a significant relationship between organizational culture and teacher performance with a path coefficient of 0.056 (7) There is a significant relationship between work motivation and teacher performance with a path coefficient of 0.320 (8) There is an indirect relationship between servant leadership and teacher performance through motivation work (9) There is an indirect relationship between principals' managerial competence and teacher performance through work motivation (10) There is an indirect relationship between organizational culture and teacher performance through work motivation (11) There is a significant simultaneous relationship between servant leadership, principal managerial competence , organizational culture with teacher performance through work motivation (12) There is a significant simultaneous relationship between servant leadership, principal managerial competence, organizational culture, and work motivation with teacher performance. The conclusion of this study is that there is a relationship between servant leadership, principal managerial competence, organizational culture, and work motivation with teacher performance in the Tunjung PAUD in North Denpasar District.

Keywords: servant leadership, managerial competence, organizational culture, work motivation, teacher performance

\section{PENDAHULUAN}

Salah satu upaya untuk mempersiapkan sumber daya manusia dalam menghadapi era globalisasi adalah melalui pendidikan. Pendidikan memegang peranan yang sangat penting dalam suatu proses peningkatan sumber daya manusia. Maju mundurnya suatu bangsa sangat ditentukan oleh kualitas pendidikan bangsa tersebut, sebagaimana dicantumkan dalam Undang-Undang Nomor 20 Tahun 2003 tentang Sistem Pendidikan Nasaional pada Pasal 3 tentang fungsi dan tujuan pendidikan nasional, bahwa pendidikan nasional berfungsi mengembangkan peradaban bangsa yang bermartabat dalam rangka mencerdaskan kehidupan bangsa, serta bertujuan untuk berkembangnya potensi peserta didik agar menjadi manusia yang beriman dan bertakwa kepada Tuhan Yang Maha Esa, berakhlak mulia, sehat, berilmu, cakap, kreatif, mandiri, dan menjadi warga Negara yang demokratis serta bertanggung jawab. Setiap warga negara wajib mengikuti Pendidikan dasar dan pemerintah wajib membiayainya. Pendidikan merupakan suatu usaha yang dilakukan oleh seseorang untuk menambah suatu ilmu pengetahuan yang sangat penting pada era globalisasi ini, serta dianggap penting untuk mendapatkan ilmu yang baru. Peranan professional guru dalam keseluruhan program pendidikan di sekolah diwujudkan untuk mencapai tujuan pendidikan yang berupa perkembangan siswa secara optimal. Maka, sebagai tenaga pendidik professional, dituntut memiliki empat kompetensi dasar yang meliputi: (1) kompetensi pedagogik; (2) kompetensi kepribadian; (3) kompetensi professional; dan (4) kompetensi sosial. Selanjutnya Undang-Undang Nomor 20 Tahun 2003 tentang Sistem Pendidikan Nasional ini dijabarkan lagi dalam beberapa peraturan antara lain Peraturan Pemerintah Nomor 19 Tahun 2005 tentang Standar Nasional Pendidikan. Standar Nasional Pendidikan adalah kriteria minimal tentang sistem Pendidikan diseluruh wilayah hukum Negara Kestuan Republik Indonesia. Hukum di Indonesia berdasarkan Peraturan Pemerintah Nomor 19 Tahun 2005 ini mengakui jalur pendidikan formal, yaitu jalur pendidikan yang terstruktur dan berjenjang yang terdiri atas pendidikan dasar, pendidikan menengah, dan pendidikan tinggi, dan jalur pendidikan non formal, yaitu jalur pendidikan diluar pendidikan formal yang dapat dilaksanakan secara terstruktur dan berjenjang. kinerja 
merupakan suatu hasil kerja seseorang atau kelompok dalam suatu organisasi berdasarkan dengan standar kerja tertentu yang telah ditetapkan oleh organisasi atau perusahaan dalam periode tertentu. Dalam rangka mencapai tujuan dari organisasi atau perusahaan yang diharapkan dan pencapaian yang hendak dicapai. Dalam penelitian ini, kinerja merupakan hasil kerja guru dalam suatu Lembaga sekolah berdasarkan dengan standar kerja tertentu yang telah ditetapkan sekolah dalah periode tertentu. Dalam rangka mencapai tujuan sekolah yang diharapkan.

Dalam Peraturan Pemerintah ini pada prinsipnya memuat standar Pendidikan untuk jenjang Pendidikan Anak Usia Dini (PAUD), Pendidikan dasar (SD dan SMP), dan Pendidikan menengah (SMA dan SMK) yang secara keseluruhan terdiri atas delapan Standar Nasional Pendidikan yang terdiri dari; (1) Standar Isi, (2) Standar Proses, (3) Standar Kompetensi Lulusan, (4) Standar Pendidik dan Tenaga Kependidikan, (5) Standar Sarana dan Prasarana, (6) Standar Pengelolaan, (7) Standar Pembiayaan, dan (8) Standar Penilaian.

Pendidikan anak usia dini diselenggarakan sebelum jenjang pendidikan dasar yang dapat diselenggarakan melalui jalur pendidikan formal, pendidikan nonformal, dan pendidikan informal. Ketentuan dalam pendidikan anak usia dini pada jalur pendidikan formal berbentuk Taman Kanak-kanak (TK) sedangkan pendidikan nonformal berbentuk Kelompok Bermain (KB), Taman Penitipan Anak (TPA), atau berbentuk lain yang sederajat. Setelah dicermati tentang tugas utama guru sebagaimana yang sudah dipaparkan diatas, maka guru sebagai tenaga pelaksana utama program-program pendidikan pada satuan pendidikan memiliki tugas yang penting dalam mengembangkan peserta didiknya sebagai calon generasi penerus bangsa di masa depan. Tugas guru yang berat dan penting ini tidak bisa dilakukan dengan setengah hati, melainkan harus dengan penuh kesungguhan, ketulusan, kegigihan, komitmen moral yang tinggi, kinerja yang baik, serta dituntut pula memiliki kemampuan professional yang memadai. Dalam implementasinya di sekolah, tujuan tersebut diatas dapat diperankan oleh kepala sekolah dalam mengelola pengembangan kinerja guru, baik dalam perencanaan, pengorganisasian, pelaksanaan, pengawasan, dan pengendalian pendidikan sekolah. Kepala sekolah dituntut untuk dapat mengembangkan berbagai potensi dan kemampuannya dalam aspek manajerial dalam mengelola sumber daya sekolah sesuai dengan kemampuan dan kebutuhannya. Salah satu sumber daya sekolah yang sangat penting dalam mengembangkan mutu sekolah adalah tenaga pendidik khususnya guru, dimana seorang guru yang memiliki tugas dan peran yang sangat besar untuk mengoptimalkan potensi yang dimiliki oleh peserta didik.

Kepemimpinan sebagai pengaruh, seni atau proses untuk mempengaruhi orangorang agar mereka mau bekerjasama dan antusias ke depan untuk mencapai suatu tujuan bersama (Deddy Mulyadi, 2015:142). Definisi kepemimpinan menurut Burns (dalam Yulk, 2005:4) menyatakan bahwa kepemimpinan dilaksanakan ketika seseorang memobilisasi sumber daya institusional, politis, psikologi, dan sumber-sumber lainnya untuk membangkitkan, melibatkan, dan memenuhi motivasi pengikutnya. Berdasarkan dari proses pemberian pengaruh yang terjadi secara alami pada sistem sosial dan yang banyak disebarkan ke pada anggota yang disebut dengan kepemimpinan. Cakupan-cakupan dalam proses kepemimpinan dimana seorang pemimpin yang mampu mempengaruhi bawahannya seperti: interpretasi peristiwa eksternal oleh para anggota, pilihan suatu tujuan dan strategi yang ingin dicapai, motivasi anggota untuk mencapai tujuan tersebut, rasa saling percaya dan bekerja sama antar anggota, organisasi aktivitas kerja, pengembangan kepercayaan dan ketrampilan anggota, pembelajaran dan pembagian pengetahuan baru antar anggota, dan pembuatan daftar dukungan dan kerjasama dari orang luar (Yulk, 2005:9)

Seorang pemimpin merupakan motor atau daya penggerak dari pada semua sumbersumber, dan alat yang tersedia bagi suatu organisasi. Kepemimpinan dalam organisasi berarti penggunaan kekuasaan dan pembuatan keputusan-keputusan. Peran kepala sekolah sebagai pimpinan yang tertinggi di suatu lembaga pendidikan khususnya di Pendidikan Anak Usia Dini (PAUD), dalam hal ini sangat penting adanya untuk peningkatan kualitas pembelajaran pada masing-masing kepala sekolah yang berdampak efektif dan efisien. Menurut Janda (dalam Yukl, 2009:3) istilah kepemimpinan adalah kata yang diambil dari 
kata-kata yang umum dipakai dan merupakan gabungan dari kalimat ilmiah yang tidak didefinisikan kembali secara tepat. Maka kata ini memiliki konotasi yang tidak ada hubungannya dengan kepemimpinan sehingga mempunyai arti yang mendua.

Kepemimpinan pelayan ini Greenleaf (dalam Deddy Mulyadi, 2015:166) telah mengidentifikasi ciri khas yang penting dari kepemimpinan pelayan. Kepemimpinan pelayan yang memiliki ciri yaitu: mendengarkan, empati, menyembuhkan, kesadaran, bujukan atau persuasif, konseptualisasi, kemampuan meramalkan, kemampuan melayani, komitmen kepada pertumbuhan manusia, dan membangun masyarakat. Kepemimpinan pelayan yang diterapkan oleh kepala sekolah kepada bawahannya, menerangkan bahwa seorang kepala sekolah mampu mendekatkan diri tanpa ada jarak dengan bawahannya. Tim Dosen Administrasi Pendidikan Universitas Pendidikan Indonesia (2013:126) kepemimpinan merupakan sumbangan dari seseorang di dalam situasi-situasi kerjasama. Kepemimpinan dan kelompok adalah merupakan dua hal yang tidak dapat dipisahkan antara yang satu dengan yang lain. Kepemimpinan Pendidikan merupakan kemampuan untuk menggerakkan pelaksanaan Pendidikan, sehingga tujuan Pendidikan yang telah ditetapkan dapat tercapai secara efektif dan efisien.

Berusaha keras untuk dapat memahami dan memberikan empati kepada bawahannya. Selain kepemimpinan pelayan yang menunjang kemajuan dari kinerja guru dalam sumber daya manusia di sekolah yaitu memiliki kompetensi manajerial yang dimiliki oleh kepala sekolah sebagai penentuan suatu kualitas dari kinerja guru. Kompetensi merupakan perpaduan dari penguasaan pengetahuan, ketrampilan, nilai dan sikap yang direfleksikan dalam kebiasaan berfikir dan bertindak pada sebuah tugas/pekerjaan. Kompetensi juga menunjuk kepada kecakapan seseorang dalam menjalankan suatu tugas dan tanggung jawab yang diamanatkan kepadanya dengan hasil yang baik.

Dalam Peraturan Menteri Pendidikan Nasional Nomor 13 Tahun 2007 tentang standar kepala sekolah bahwa kompetensi yang harus dimiliki oleh kepala sekolah adalah kompetensi kepribadian, kompetensi manajerial, kompetensi kewirausahaan, kompetensi supervisi, dan kompetensi sosial. Kompetensi manajerial kepala sekolah dapat diartikan sebagai kemampuan yang mampu mengelola sumber daya melalui kegiatan perencanaa, pengorganisasian, pengarahan, dan pengawasan untuk mencapai tujuan organisasi secara efektif dan efisien. Selain dari kompetensi manajerial kepala sekolah, pentingnya juga yang berperan penting sebagai meningkatnya suatu kinerja guru dalam suatu sekolah yaitu budaya organisasi yang diterapkan oleh sekolah tersebut. Menurut Payman J. Simanjuntak (dalam Susanto, (2016:69) kinerja adalah tingkat pencapaian hasil atas pelaksanaan tugas tertentu dalam rangka pencapaian tujuan organisasi. Dalam hal ini, Simanjuntak menegaskan bahwa kinerja adalah sesuatu yang penting dalam rangka pencapaian tujuan organisasi, karena setiap individua tau organisasi tentu saja memiliki tujuan yang akan dicapai dengan menetapkan target atau sasaran. Keberhasilan individu atau organisasi dalam mencapai target atau sasaran tersebut itulah merupakan kinerja.

Budaya organisasi yang diterapkan di masing-masing sekolah pastilah berbeda-beda. Dilihat dari visi, misi dan tujuan dari sekolah tersebut. Budaya organisasi merupakan aturan main atau acuan (nilai-nilai, norma-norma, falsafah, dan keyakinan) suatu organisasi atau komunitas tertentu yang dipahami oleh seluruh anggota organisasi yang dimanifestasikan dalam pola piker dan perilaku yang terintegrasi secara internal dan adanya adaptasi secara eksternal dalam usaha mencapai tujuan organisasi (Susanto, 2016:187). Kaitannya dengan kinerja guru seperti yang sudah dijelaskan di atas, ada satu yang mendorong suatu kinerja tersebut menjadi baik dan optimal, yaitu motivasi kerja yang dimiliki oleh seorang guru. Tidak jarang ditemukan guru yang kurang memiliki gairah dalam melakukan tugasnya, yang berakibat kurang berhasilnya tujuan yang ingin dicapai. Hal itu disebabkan oleh berbagai faktor. Salah satunya yaitu kurangnya motivasi yang dimiliki oleh seorang guru. Motivasi dapat dipandang sebagai perubahan energi dalam diri seseorang yang ditandai dengan munculnya feeling, dan didahului dengan tanggapan dengan adanya tujuan. Di samping itu pula, motivasi juga dapat dinilai sebagai suatu daya dorong (driving force) yang menyebabkan orang dapat berbuat sesuatu untuk mencapai tujuan. Dalam hal ini, motivasi menunjuk pada gejala yang melibatkan dorongan perbuatan terhadap tujuan tertentu. 
Motivasi adalah dorongan dasar yang menggerakkan seseorang bertingkah laku. Dorongan ini berada pada diri sesorang yang menggerakkan untuk melakukan sesuatu yang sesuai dengan dorongan dalam dirinya. Aspek kinerja ini berhubungan dengan motivasi yang dimiliki oleh seseorang. Berdasarkan uraian latar belakang masalah di atas, maka ada hubungan yang sangat erat antara kepemimpinan pelayan, kompetensi manajerial kepala sekolah, budaya sekolah, dan motivasi kerja dikaitkan dengan kinerja guru. Untuk itulah maka penulis mencoba mengadakan suatu penelitian dengan mengambil topik seperti tercantum di atas dengan judul "Hubungan Kepemimpinan Pelayan, Kompetensi Manajerial Kepala Sekolah, Budaya organisasi, dan Motivasi Kerja Dengan Kinerja Guru di Gugus PAUD Tunjung Kecamatan Denpasar Utara".

\section{METODE}

Rancangan penelitian yang digunakan dalam penelitian ini adalah ex post facto dengan desain penelitian deskriptif dan korelasional. Penelitian ex post facto merupakan suatu pendekatan pada subjek penelitian untuk meneliti yang telah dimiliki oleh subjek penelitian secara wajar tanpa adanya usaha sengaja memberikan perlakuan untuk memunculkan variabel yang ingin diteliti, dan desain penelitian ex post facto terdiri dari korelasional dan komparatif (Dantes, 2012:59). Maka penelitian ini tergolong ex post facto dengan desain penelitian dekriptif dan korelasional. Dikatakan penelitian deskriptif dikarenakan peneliti berusaha mendeskripsikan suatu fenomena atau peristiwa secara sistematis sesuai dengan apa adanya untuk memperoleh informasi dan selanjutnya mendeskripsikan data tentang objek atau variabel yang diteliti (Dantes, 2012:51). Dalam penelitian ini, berusaha untuk mendeskripsikan data tentang objek atau variabel penelitian yang ada pada Gugus PAUD Tunjung Kecamatan Denpasar Utara.

Variabel merupakan suatu konsep sangat penting di dalam penelitian. Keberadaan variabel dalam suatu penelitian menjadi suatu keharusan. (Agung, 2017:41). Maka dari kelima dari variabel di atas, dapat digolongkan ke dalam beberapa variabel yaitu, variabel bebas, variabel terikat, dan variabel antara. Dalam hal ini bahwa pada suatu model jalur pada umumnya terdiri dari sekurang-kurangnya dua variabel bebas atau eksogen (exogenous) dan variabel terikat atau endogen (endogeneous), serta pada kasus tertentu ada variabel antara (intervening) (Nidjo Sandjojo, 2011:18). Dalam penelitian ini melibatkan tiga variabel bebas yaitu, kepemimpinan pelayan $\left(X_{1}\right)$, kompetensi manajerial kepala sekolah $\left(\mathrm{X}_{2}\right)$, budaya organisasi $\left(\mathrm{X}_{3}\right)$, dan melibatkan satu variabel mediator yaitu, motivasi kerja $\left(\mathrm{X}_{4}\right)$, serta melibatkan satu variabel terikat yaitu, kinerja guru $(Y)$. Sehingga, variabel-variabel yang diteliti ini berdasarkan sesuai dengan variabel endogeneous dan variabel exogeneous yang terkandung di dalamnya, maka dari itu model hubungannya terbagi atas dua blok. Blok 1 mempunyai variabel exogeneous adalah kepemimpinan pelayan, kompetensi manajerial kepala sekolah, dan budaya organisasi dengan variabel endogenous motivasi kerja. Blok 2 sebagai variabel exogeneous adalah kepemimpinan pelayan, kompetensi manajerial kepala sekolah, budaya organisasi, dan motivasi kerja dengan variabel endogeneous adalah kinerja guru. Maka, berdasarkan model hubungan dalam penelitian ini untuk analisis data yang digunakan adalah teknik analisis jalur (path analysis). Analisis jalur digunakan untuk menganalisis suatu hubungan yang kausal antar variabel untuk mengetahui baik pengaruh langsung maupun pengaruh tidak langsung diantara variabel bebas dengan variabel terikat. Apabila dalam suatu penelitian tidak ada hubungan antara variabel bebas yang satu dengan variabel bebas yang lainnya, dan masing-masing variabel bebas hanya mempunyai hubungan langsung dengan variabel terikat, maka digunakan teknik analisis regresi sebagai analisis data. Sebaliknya, jika di antara variabel bebas yang satu dengan hubungan dengan variabel bebas lainnya, dan mempunyai hubungan langsung ataupun tidak langsung dengan variabel terikat, maka digunakan analisis jalur (path analysis).

Sebelum dilaksanakan analisis jalur (Path Analysis), data harus memenuhi beberapa persyaratan uji statistik, yaitu (1) uji normalitas, (2) uji linieritas, (3) uji autokorelasi, (4) uji heterokedastisitas, (5) uji multikolonieritas. Populasi adalah keseluruhan objek dalam suatu penelitian (Agung, 2017:74). Populasi yang digunakan dalam penelitian ini adalah seluruh guru di Gugus PAUD Tunjung Kecamatan Denpasar Utara, dalam hal ini terdapat sebanyak 
8 sekolah PAUD yang tergabung dalam Gugus Tunjung Kecamatan Denpasar Utara. Populasi guru di Gugus PAUD Tunjung Kecamatan Denpasar Utara berjumlah 50 orang. Keseluruhan jumlah guru di Gugus PAUD Tunjung digunakan sebagai populasi dalam penelitian ini. Sampel adalah sebagian dari populasi yang diambil dan dianggap mewakili seluruh populasi dengan menggunakan teknik tertentu (Agung, 2017:74). Dalam penelitian ini, teknik penentuan sampel yang digunakan adalah studi populasi. Pengertian dari studi populasi adalah teknik penentuan sampel bila semua anggota populasi digunakan sebagai sampel. Dalam hal ini, kepala sekolah dan jumlah seluruh guru pada 8 sekolah yang ada di Gugus PAUD Tunjung Kecamatan Denpasar Utara yang akan digunakan sebagai populasi sekaligus sampel yaitu berjumlah 50 orang.

\section{HASIL DAN PEMBAHASAN}

Berdasarkan hasil analisis model struktural dengan analisis jalur (path analysis) dalam penelitian ini telah berhasil mengidentifikasi model struktural yang memiliki kelayakan untuk dapat dijadikan model struktural. Dengan kata lain, model tersebut memiliki nilai prediksi yang relevan. Model struktural yang diperoleh tersebut menunjukkan ada hubungan langsung atau tidak langsung antara kepemimpinan pelayan, kompetensi manajerial kepala sekolah, budaya organisasi, dan motivasi kerja dengan kinerja guru.

Berikut ini pembahasan difokuskan pada hubungan-hubungan variabel laten eksogen $X$ (kepemimpinan pelayan, kompetensi manajerial kepala sekolah, budaya organisasi, dan motivasi kerja) dengan variabel laten endogen $Y$ (kinerja guru). Fokus pada variabel endogen $Y$ ini dilakukan, karena dalam penelitian ini variabel kinerja guru merupakan variabel kriterium, yaitu variabel yang menjadi titik fokus utama dalam kajian penelitian ini. Berangkat dari konsep pikir tersebut, dapat dipaparkan pembahasan hasil uji hipotesis penelitian sebagai berikut. (1) Ada hubungan yang signifikan antara kepemimpinan pelayan dengan motivasi kerja dengan koefisien jalur sebesar 0,433. (2) Ada hubungan yang signifikan antara kompetensi manajerial kepala sekolah dengan motivasi kerja dengan koefisien jalur sebesar 0,209. Hasil analisis data menunjukkan bahwa ada hubungan secara langsung yang signifikan kompetensi manajerial kepala sekolah dengan kinerja guru. Keahlian manajerial di dalam manajemen kepala sekolah sangat diperlukan, dimana seseorang dapat dikatakan kompeten di bidang tertentu jika menguasai kecakapan bekerja sebagai satu keahlian selaras dengan bidangnya. Kepala sekolah dalam mengelola satuan pendidikan disyaratkan menguasai ketrampilan dan kompetensi tertentu yang dapat mendukung pelaksanaan tugasnya. (3) Ada hubungan yang signifikan antara budaya organisasi dengan motivasi kerja dengan koefisien jalur sebesar 0,297. (4) Ada hubungan yang signifikan antara kepemimpinan pelayan dengan kinerja guru dengan koefisien jalur sebesar 0,132. (5) Ada hubungan yang signifikan antara kompetensi manajerial kepala sekolah dengan kinerja guru dengan koefisien jalur sebesar 0,398 (6) Ada hubungan yang signifikan antara budaya organisasi dengan kinerja guru dengan koefisien jalur sebesar 0,056 (7) Ada hubungan yang signifikan antara motivasi kerja dengan kinerja guru dengan koefisien jalur sebesar 0,320 (8) Ada hubungan secara tidak langsung antara kepemimpinan pelayan dengan kinerja guru melalui motivasi kerja. Hasil analisis data menunjukkan bahwa ada hubungan secara langsung yang signifikan kepemimpinan pelayan dengan kinerja guru. Hal ini menunjukkan bahwa kepemimpinan pelayan dapat mempengaruhi secara langsung kinerja guru. Kepemimpinan dalam penerapan manajemen sekolah memerlukan dua ketrampilan yaitu ketrampilan memimpin dan ketrampilan mengelola (kepemimpinan dan manajerial). Perilaku kepemimpinan dalam melaksanakan ketrampilan ini memegang peranan yang sangat penting untuk meningkatkan kualitas sekolah. (9) Ada hubungan secara tidak langsung antara kompetensi manajerial kepala sekolah dengan kinerja guru melalui motivasi kerja. Hasil analisis data menunjukkan bahwa ada hubungan secara langsung yang signifikan budaya organisasi terhadap kinerja guru. Hasil analisis data menunjukkan bahwa ada hubungan secara tidak langsung yang signifikan budaya organisasi terhadap kinerja guru. (10) Ada hubungan secara tidak langsung antara budaya organisasi dengan kinerja guru melalui motivasi kerja (11) Ada hubungan secara simultan yang 
signifikan antara kepemimpinan pelayan, kompetensi manajerial kepala sekolah, budaya organisasi dengan kinerja guru melalui motivasi kerja (12) Ada hubungan secara simultan yang signifikan antara kepemimpinan pelayan, kompetensi manajerial kepala sekolah, budaya organisasi, dan motivasi kerja dengan kinerja guru.

\section{SIMPULAN DAN SARAN}

Berdasarkan hasil analisis dan pembahasan hasil penelitian, maka dapat disimpulkan hal-hal sebagai berikut. (1) Hasil uji hipotesis 1 menyimpulkan ada hubungan secara langsung yang signifikan kepemimpinan pelayan dengan motivasi kerja guru di Gugus PAUD Tunjung Kecamatan Denpasar Utara. Artinya bahwa semakin tinggi kadar kepemimpinan pelayan kepala sekolah maka diikuti oleh sesemakin tinggi pula motivasi kerja. Dan sebaliknya, semakin rendah kepemimpinan pelayan kepala sekolah maka sesemakin rendah pula motivasi kerja. (2) Hasil uji hipotesis 2 menyimpulkan ada hubungan secara langsung yang signifikan kompetensi manajerial kepala sekolah dengan motivasi kerja guru di Gugus PAUD Tunjung Kecamatan Denpasar Utara. Artinya bahwa semakin tinggi kadar kompetensi manajerial kepala sekolah maka diikuti oleh semakin tinggi pula motivasi kerja. Dan sebaliknya, semakin rendah kompetensi manajerial kepala sekolah maka semakin rendah pula motivasi kerja. (3) Hasil uji hipotesis 3 menyimpulkan ada hubungan secara langsung yang signifikan budaya organisasi dengan motivasi kerja guru di Gugus PAUD Tunjung Kecamatan Denpasar Utara. Artinya bahwa semakin tinggi kadar budaya organisasi maka diikuti oleh semakin tinggi pula motivasi kerja. Dan sebaliknya, semakin rendah budaya organisasi maka semakin rendah pula motivasi kerja. (4) Hasil uji hipotesis 4 menyimpulkan ada hubungan secara langsung yang signifikan kepemimpinan pelayan dengan kinerja guru di Gugus PAUD Tunjung Kecamatan Denpasar Utara. Artinya bahwa semakin tinggi kadar kepemimpinan pelayan kepala sekolah maka diikuti oleh sesemakin tinggi pula kinerja guru. Dan sebaliknya, semakin rendah kepemimpinan pelayan kepala sekolah maka sesemakin rendah pula kinerja guru. (5) Hasil uji hipotesis 5 menyimpulkan ada hubungan secara langsung yang signifikan kompetensi manajerial kepala sekolah dengan kinerja guru di Gugus PAUD Tunjung Kecamatan Denpasar Utara. Artinya bahwa semakin tinggi kadar kompetensi manajerial kepala sekolah maka diikuti oleh semakin tinggi pula kinerja guru. Dan sebaliknya, semakin rendah kompetensi manajerial kepala sekolah maka semakin rendah pula kinerja guru. (6) Hasil uji hipotesis 6 menyimpulkan ada hubungan secara langsung yang signifikan budaya organisasi dengan kinerja guru di Gugus PAUD Tunjung Kecamatan Denpasar Utara. Artinya bahwa semakin tinggi kadar budaya organisasi maka diikuti oleh semakin tinggi pula kinerja guru. Dan sebaliknya, semakin rendah budaya organisasi maka semakin rendah pula kinerja guru. (7) Hasil uji hipotesis 7 menyimpulkan ada hubungan secara langsung yang signifikan motivasi kerja dengan kinerja guru di Gugus PAUD Tunjung Kecamatan Denpasar Utara. Artinya bahwa semakin tinggi kadar motivasi kerja maka diikuti oleh semakin tinggi pula kinerja guru. Dan sebaliknya, semakin rendah motivasi kerja maka semakin rendah pula kinerja guru. (8) Hasil uji hipotesis 8 menyimpulkan ada hubungan secara tidak langsung yang signifikan kepemimpinan pelayan dengan kinerja guru melalui motivasi kerja di Gugus PAUD Tunjung Kecamatan Denpasar Utara. Artinya bahwa untuk meningkatkan kinerja guru cukup efektif dengan mengubah atau meningkatkan motivasi kerja disamping juga dengan meningkatkan kepemimpinan pelayan kepala sekolah. Sebab motivasi kerja maupun kepemimpinan pelayan kepala sekolah ternyata sama-sama efektif untuk meningkatkan kinerja guru. (9) Hasil uji hipotesis 9 minyimpulkan ada hubungan secara tidak langsung yang signifikan kompetensi manajerial kepala sekolah dengan kinerja guru melalui motivasi kerja di Gugus PAUD Tunjung Kecamatan Denpasar Utara. Artinya bahwa untuk meningkatkan kinerja guru cukup efektif dengan mengubah atau meningkatkan motivasi kerja disamping juga dengan meningkatkan kompetensi manajerial kepala sekolah. Sebab motivasi kerja maupun kompetensi manajerial kepala sekolah ternyata sama-sama efektif untuk meningkatkan kinerja guru. (10) Hasil uji hipotesis 10 menyimpulkan ada hubungan secara tidak langsung yang signifikan budaya organisasi dengan kinerja guru melalui motivasi kerja di Gugus PAUD Tunjung Kecamatan Denpasar Utara. Artinya bahwa untuk meningkatkan kinerja guru cukup efektif dengan mengubah atau meningkatkan 
motivasi kerja disamping juga dengan maningkatkan kondisi budaya organisasi sekolah. Sebab motivasi kerja maupun budaya organisasi ternyata sama-sama efektif untuk meningkatkan kinerja guru. (11) Hasil uji hipotesis 11 menyimpulkan ada hubungan secara simultan yang signifikan kepemimpinan pelayan, kompetensi manajerial kepala sekolah, dan budaya organisasi dengan kinerja guru melalui motivasi kerja di Gugus PAUD Tunjung Kecamatan Denpasar Utara. Artinya bahwa secara gabungan ketiga variabel bebas kepemimpinan pelayan, kompetensi manajerial, dan budaya organisasi sangat efektif untuk meningkatkan motivasi kerja, dan untuk meningkatkan kinerja guru cukup efektif dengan mengubah atau meningkatkan motivasi kerja disamping juga dengan meningkatkan ketiga variabel bebas. (12) Hasil uji hipotesis 12 menyimpulkan ada hubungan secara simultan yang signifikan kepemimpinan pelayan, kompetensi manajerial kepala sekolah, budaya organisasi, dan motivasi kerja dengan kinerja guru di Gugus PAUD Tunjung Kecamatan Denpasar Utara. Artinya bahwa secara gabungan keempat variabel bebas tersebut sangat efektif untuk meningkatkan kinerja guru pada kalangan guru.

\section{UCAPAN TERIMAKASIH}

Ucapan terima kasih saya ucapkan kepada: (1) Prof. Dr. A.A.Gede Agung, M.Pd selaku Pembimbing I yang telah dengan sabar memberikan bimbingan, arahan, petunjuk dan motivasi yang sangat bermakna, sehingga penulis mampu melewati berbagai kendala dan hambatan dalam penyelesaian tesis ini. (2) Dr. Sudirman, MLS, selaku Pembimbing II yang telah dengan sabar memberikan bimbingan, arahan, petunjuk dan motivasi, sehingga penulis mampu melewati berbagai kendala dan hambatan dalam penyelesaian tesis ini. (3) Kepala sekolah dan guru-guru di Gugus PAUD Tunjung Kecamatan Denpasar Utara yang telah berkenan memberikan ijin untuk mengadakan penelitian dan memberikan segala informasi dalam pengumpulan data. (3) Teman-teman satu angkatan di Program Studi Administrasi Pendidikan yang telah membatu, saling support, dan memberikan sumbang saran baiksecara langsung maupun tidak langsung dalam pengerjaan tesis ini. (4) Keluarga tercinta, ibu, almarhum bapak, adik, suami dan anakku Sagha serta semua pihak yang tidak bisa disebutkan satu per satu yang telah memberikan doa, dukungan, motivasi lahir dan batin agar penyusunan tesis ini dapat diselesaikan.

\section{DAFTAR PUSTAKA}

Agung, A.A. Gede. 2017. Metodologi Penelitian Kuantitatif. Singaraja: Undiksha Press.

Agung, A.A. Gede. 2017. Statistika Inferensial untuk Pendidikan (Disertai Aplikasi SPSS). Singaraja: Undiksha Press

Dantes, Nyoman. 2012. Metode Penelitian. Yogjakarta: Penerbit Andi.

Lantu, dkk. 2007. Servant Leadership. Jakarta: Gradien Books

Mulyadi, Deddy. 2015. Perilaku Organisasi dan Kepemimpinan Pelayan (Konsep dan Aplikasi administrasi, Manajemen, dan Organisasi Modern). Bandung: Penerbit Alfabeta Bandung

Peraturan Menteri Pendidikan Nasional Republik Indonesia Nomor 13 Tahun 2007 tentang Standar Kompetensi Kepala Sekolah/Madrasah.

Peraturan Menteri Pendidikan Nasional Republik Indonesia Nomor 22 Tahun 2006 tentang Standar Isi untuk Satuan Pendidikan Dasar dan Menengah.

Peraturan Pemerintah Nomor 19 Tahun 2005 tentang Standar Nasional Pendidikan.

Sugiyono, 2006. Metode penelitian. Bandung: Alfabeta Bandung. 
Susanto, Ahmad. 2016. Manajemen Peningkatan Kinerja Guru. Jakarta: Penerbit Prenamedia Group.

Tim Dosen Administrasi Pendidikan Universitas Pendidikan Indonesia, 2013. Manajemen Pendidikan. Bandung: Alfabeta

Undang-Undang Republik Indonesia Nomor 20 Tahun 2003 tentang Sistem Pendidikan Nasional.

Undang-Undang Republik Indonesia Nomor 22 Tahun 2003 tentang Pemerintahan Daerah

Universitas Pendidikan Ganesha. 2016. Pedoman Penulisan Karya Ilmiah: Tugas Akhir, Skripsi, Tesis, dan Desertasi. Singaraja: Penerbit Undiksha.

Universitas Pendidikan Ganesha. 2017. Pedoman Penulisan Karya Ilmiah: Tugas akhir, skripsi, Tesis, dan Disertasi. Singaraja: Penerbit Undiksha.

Yukl, Gary. 2013. Kepemimpinan Dalam Organisasi. Alih Bahasa oleh Budi Supriyanto. Jakarta: Penerbit PT. Indeks. 